\title{
André de Mandach, Les modèles anglo-normands de Chrétien. Chrétien en Angleterre
}

\section{G. Matteo Roccati}

\section{Q OpenEdition}

12 Journals

\section{Édition électronique}

URL : http://journals.openedition.org/studifrancesi/34232

DOI : $10.4000 /$ studifrancesi.34232

ISSN : 2421-5856

Éditeur

Rosenberg \& Sellier

\section{Édition imprimée}

Date de publication : 1 novembre 2005

Pagination : 386

ISSN : 0039-2944

\section{Référence électronique}

G. Matteo Roccati, «André de Mandach, Les modèles anglo-normands de Chrétien. Chrétien en

Angleterre », Studi Francesi [En ligne], 146 (XLIX | II) | 2005, mis en ligne le 30 novembre 2015, consulté le 22 avril 2021. URL : http://journals.openedition.org/studifrancesi/34232 ; DOI : https://doi.org/ 10.4000/studifrancesi.34232

Ce document a été généré automatiquement le 22 avril 2021.

\section{(c)}

Studi Francesi è distribuita con Licenza Creative Commons Attribuzione - Non commerciale - Non opere derivate 4.0 Internazionale. 


\title{
André de Mandach, Les modèles anglo-normands de Chrétien. Chrétien en Angleterre
}

\author{
G. Matteo Roccati
}

\section{RÉFÉRENCE}

ANDRÉ DE MANDACH, Les modèles anglo-normands de Chrétien. Chrétien en Angleterre, «Romanistische Zeitschrift für Literaturgeschichte - Cahiers d'Histoire des Littératures Romanes», 25, 3/4, 2001, pp. 283-293.

1 L'article réunit quelques exemples tirés d'un ouvrage à paraître sur les modèles anglonormands d'Erec et Enide, exemples prouvant l'existence d'intermédiaires anglonormands entre les récits celtiques et Chrétien: l'explication par un calque syntagmatique gallois des noms des chevaux d'Arthur et Gauvain, la localisation de la terre du comte de Limors près de Vannes, les parentés dans la description de certains duels entre Gereint ac Enid, Le Bel Inconnu et Erec et Enide, etc. Il suppose que Chrétien a résidé dans la région des Midlands et de Norfolk et propose, à titre d'hypothèse, de l'identifier avec un Chrétien, prieur clunisien de Thetford (Norfolk). 